\title{
ANALYSIS OF EXPOSED AND ACCUMULATED LEAD CONCENTRATION ON GOLDFISH GILLS (CYPRINUS CARPIO)
}

\author{
Waromi Rosalia, Student \\ Musa Muhammad, Kurniawan Andi, Lecturers \\ Faculty of Fisheries and Marine Sciences, Brawijaya University, Indonesia
}

*E-mail: rwaromy@yahoo.com

\begin{abstract}
The purpose of this study is to analyze exposed and accumulated $\mathrm{Pb}$ concentration on goldfish gills (Cyprinus carpio). The method used is the experimental method and the design used in this research is Completely Randomized Design (RAL) consisting of four treatments and three replications. The goldfish were exposed to $\mathrm{Pb}\left(\mathrm{NO}_{3}\right)_{2}$ according to treatment and replication. Research result exhibited that $\mathrm{Pb}$ concentration in goldfish gills would accumulate as toxic in relatively small amounts on all treatments on the first day at $2.01 \mathrm{mg} / \mathrm{l}$ and control treatment (K1) of $2.36 \mathrm{mg} / \mathrm{l}$ at day-21. The highest concentration of $\mathrm{Pb}$ exposed and accumulated on goldfish gills was found in treatment 3 (L3) of $5.92 \mathrm{mg} / \mathrm{l}$ on day 21.
\end{abstract}

\section{KEY WORDS}

Lead, goldfish, concentration, gills.

Over time the use of heavy metal lead $(\mathrm{Pb})$ is widely used in a variety of human activities such as the manufacture of batteries, ammunition, cables, lead plates, solder, pipes, paint, glass, ceramics, domestic waste, transportation and wastewater of lead mining (Lu, 1995). Water containing leads is caused by crystallization in the air. After a rain the lead is infused into waters, weathering rocks, the activity of the volcano and the process of erosion. One of the commonly used forms of $\mathrm{Pb}$ is $\mathrm{Pb}\left(\mathrm{NO}_{3}\right)_{2}$ which can cause pollution in the aquatic environment. It poses serious problems for the survival of aquatic organisms when they are exposed to it. Especially when it accumulated and exceeds the threshold. Aquatic organisms affected by $\mathrm{Pb}\left(\mathrm{NO}_{3}\right)_{2}$ are fish such as goldfish. Based on Khairuman's opinion (2005), goldfish (Cyprinus carpio) is one type of freshwater fish possessing high economic value and potential to be cultivated for a relatively short period of maintenance. Therefore goldfish is classified as a creature which is responsive to the environment. In addition, this particular fish can be used to evaluate the pollution levels of aquatic ecosystems. This goldfish can accumulate pollutants through the food chain (Farkas et al., 2002; Al and El, 1999).

Lead is one type of heavy metal that can cause water pollution. Water polluted by $\mathrm{Pb}$ will have an impact on aquatic organisms (Ade et al., 2010). In order to determine the concentration of heavy metals in an aquatic organism, researchers used AAS method. AAS is a tool used to measure heavy metal components by absorbing light according to certain wavelengths by metal atoms in free conditions (Skoog et al., 2004).

The heavy metals that stay for long periods in the body of the organism will accumulate as toxins (Palar, 1994). Heavy metals in water will undergo a process of settling, absorption, and accumulated in sediments and aquatic organisms. There are several methods of heavy metals accumulation: through the skin, respiratory tract and food chain (Jardin, 1993).

Each type of heavy metal entering a water has different concentrations, but it will still pollute the aquatic environment and accumulate in the organism body. Before toxic heavy metals are dispersed throughout the body of the organism, it had to pass through the membrane and cell. Cell membrane will respond to heavy metals as a modification of cell membrane permeability. It would cause a disruption of ATP production resulting in disruption of the ion transfer system (Connell and Miller, 1995). This research has the purpose to know 
the analysis of exposed and accumulated lead concentration $(\mathrm{Pb})$ on goldfish gills (Cyprinus carpio).

\section{LITERATURE REVIEW}

Heavy Metals Lead $(\mathrm{Pb})$. Lead $(\mathrm{Pb})$ is one of the heavy metals that have the effect of poisonous and dangerous because it is both as pollutants and reactive interfere with survival of organisms that are in the waters. Lead or lead, in the scientific language called plumbum (Sumah and Aunurohim, 2013:7-8).

Mechanism of heavy metal's entry into the body of the fish through three phases namely: 1) through respiration or gills that absorb heavy metals. 2) through the food chain that is absorbed by the gastrointestinal tract and 3) the absorption of water into the surface of the body. The spread of toxic substances or heavy metals into the body will lead to damage to the permeability of the membrane so that it will interfere with the process of the formation of ATP followed by disruption of the system displacement of ions in the body (Connel and Miller, 1995:16-17).

Accumulation of Heavy Metals Lead $(\mathrm{Pb})$. Waters that are contaminated or exposed by the heavy metals will affect aquatic organisms that live in it as with any other fish or goldfish. Accumulation in organime life can occur due to heavy metals that go into his body will form chemical bonds form complexes with organic substances found in the body. This impact of heavy metals is not fixed out of the body and stored in it (Benny et al., 2016:16-17). The process of accumulation of heavy metals in fish may occur in the physical or biological (biochemical). The physical process is the stick to heavy metal compounds on the surface of the body, the body, the Gill and other membrane holes sourced from water as well as compounds that stick to the pertikel. Biological process occurs through the process of the food chain that's been exposed and terinjek by heavy metals

(Nana, 2012:16-17). Lead is highly toxic heavy metals, have the nature of bioakumulatif in body organism and will hold water in accumulated until such organisms aren't able to tolerate the heavy metal content of lead in the body (Connell and Miller, 1995). Based on the opinion of the palar (2004) mention that the waters containing compounds or $\mathrm{Pb}$ ions which have a fairly high concentrations can cause death for biota living in the waters, where the concentration of $\mathrm{Pb}$ that reaches $188 \mathrm{mg} / \mathrm{l}$ can kill or resulting in death on fishes.

\section{METHODS OF RESEARCH}

The method used in this study is an experimental method, this method is a method of experiment used to investigate and test a theory to see a result of the variables or causal relationships that deserve to be investigated. Khotimah et al., (2013), states that The experimental method is to conduct experimental activities to determine a result. The results will confirm how the position of the causal relationship between variables is investigated. This research was executed from February to April - May 2018. This research was conducted in two laboratories: Fish Cultivation Laboratory FPIK and Chemistry Laboratory FMIPA University Of Brawijaya Malang East Java.

The design used in this study was Completely Randomized Design (RAL) consisting of four treatments and three replications. Goldfish live media was exposed to $\mathrm{Pb}\left(\mathrm{NO}_{3}\right)_{2}$ solution according to treatment and replication.

\section{RESULTS AND DISCUSSION}

Based on the measurement on exposed and accumulated $\mathrm{Pb}$ in goldfish gills according to treatment and replication, the average concentration of lead concentration $(\mathrm{Pb})$ on goldfish gills (Cyprinus carpio) is exhibited in the Table 1.

Based on the results of Table 1 above it can be seen that during the 1st day all treatments do not change significantly. On the other hand the 21st day, each treatment undergoes significant changes or continue to increase in each treatment given. The 
treatments are: control treatment (K1) without administration of lead exposure of nitric acid, treatment 1 ( $\mathrm{L} 1)$ with $\mathrm{Pb}\left(\mathrm{NO}_{3}\right)_{2}$ exposure $0.3 \mathrm{mg} / \mathrm{l}$, treatment 2 (L2) with $\mathrm{Pb}\left(\mathrm{NO}_{3}\right)_{2}$ exposure $0.36 \mathrm{mg} / \mathrm{l}$ and treatment $3(\mathrm{~L} 3)$ with $\mathrm{Pb}\left(\mathrm{NO}_{3}\right)_{2}$ exposure $0.45 \mathrm{mg} / \mathrm{l}$.

Table 1 - Average Measurement of Lead Concentration $(\mathrm{Pb})$ on Goldfish gills (Cyprinus carpio)

\begin{tabular}{|c|c|c|c|c|}
\hline Day & K1 & L1 & L2 & L3 \\
\hline 1 & 2.01 & 2.01 & 2.01 & 2.01 \\
\hline 21 & 2.36 & 2.49 & 4.49 & 5.92 \\
\hline
\end{tabular}

The $\mathrm{Pb}$ concentration contained in the aquatic biota is exposed $\mathrm{Pb}\left(\mathrm{NO}_{3}\right)_{2}$ on goldfish. It will be stored or accumulated from time to time. Therefore the aquatic biota can be used to indicate water pollution by heavy metals. According to Darmono (1995), the content of heavy metals in aquatic biota will usually increase over time as it is bio accumulative in nature. Therefore aquatic biota can be used as an indicator of heavy metal pollution in waters. The amount of heavy metal absorption and metal content weight in water is usually proportional, i.e the increase in heavy metal content in the tissue corresponds to the increase in the water content. In non-essential heavy metals (including lead), the content in the tissue increases steadily in accordance with the increase of heavy metal concentration.

The average result of $\mathrm{Pb}$ concentration measurement can be seen in Figure 1 below:

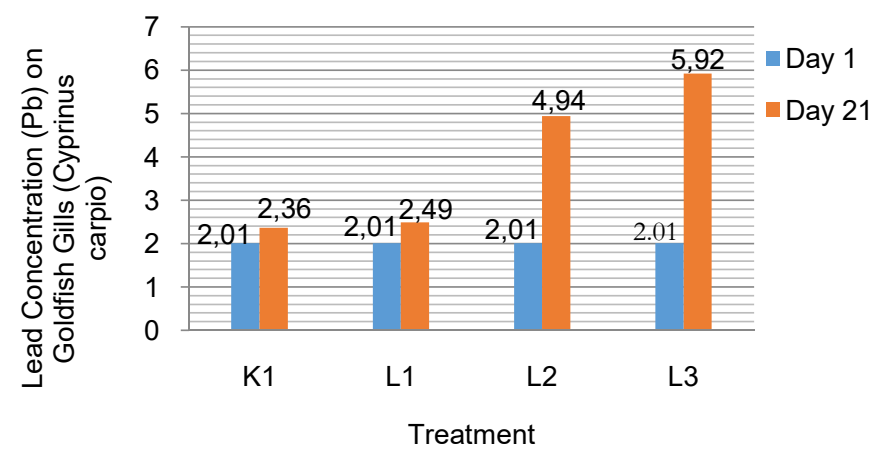

Figure 1 - Average Measurement Results of Lead Concentration on Goldfish gills (Cyprinus carpio)

The concentration of $\mathrm{Pb}$ on the gills of the goldfish will accumulate as toxic in relatively small amounts on all treatments on the first day $2.01 \mathrm{mg} / \mathrm{l}$ and the control treatment (K1) 2.36 $\mathrm{mg} / \mathrm{l}$ on the 21st day as exhibited in figure 1 above. Heavy metals are generally toxic to living things. Although some of them are needed in small quantities (Supriyanto et al., 2007). Furthermore, the highest concentration of $\mathrm{Pb}$ exposed and accumulated in goldfish gills was in treatment 3 (L3) of $5.92 \mathrm{mg} / \mathrm{l}$ on the 21st day which can be seen in Figure 1. It indicates that $\mathrm{Pb}$ may contaminate and cause toxic properties. One of the pollutants that can pose a hazard, especially for fish, is heavy metal. This occurs when a number of metals have contaminated and found in high concentrations in the waters (Ade et al., 2010).

Accumulation of heavy metals in fish can occur due to contact between medium containing toxic with fish. Contact takes place with the removal of chemicals from the water environment into or the surface of the fish body, for example, heavy metals entering through the gills. The entry of heavy metals into the body of aquatic organisms occurs in three methods: through food, gills, and diffusion through the skin surface.

Gill is a respiratory organ or $\mathrm{O}_{2}$ exchange organ. It often exposed to influence from water contaminants such as $\mathrm{Pb}$. This is in accordance Wong's Opinion (2000) which suggests that gills, other than as a respirator, are also used as a means of regulating pressure between water and in the fish body (osmoregulation). Gills is the first organ that is directly related to toxic materials in the waters, with a wide and open surface, thus causing this section to be the main target for the toxic materials present in the waters. 


\section{CONCLUSION}

Based on the research result, it can be concluded that exposed and accumulated lead concentration $(\mathrm{Pb})$ on goldfish are indicated as follows: the lowest concentration was found on each day 1 treatment at $2.01 \mathrm{mg} / \mathrm{l}$. It was also found in the 21st-day control treatment (K1) $2.36 \mathrm{mg} / \mathrm{l}$. The highest concentration was found in $5.92 \mathrm{mg} / \mathrm{l}$ at treatment 3 (L3). It would pollute the aquatic environment and is considered toxic because the gill is a respirator organ directly related to water media exposed to pollutants such as lead $(\mathrm{Pb})$.

\section{SUGGESTIONS}

Based on the conclusion presented above, it can be suggested that, in addition to knowing the concentration and accumulation of lead in each treatment given and exposed to the gills of goldfish, it is necessary to do further testing of lead concentration in some other goldfish organs so that will see the level of concentration and accumulation of different leads in each organs goldfish.

\section{REFERENCES}

1. Al-Yousuf, M \& El-Shahawi, M. 1999. Trace metals in Lethrinus lentjan fish from the Arabian Gulf (Ras Al-Khaimah, United Arab Emirates): metal accumulation in kidney and heart tissues. Bull Environ Contam. Toxicol, Vol. 3 (62), p. 293-300.

2. Connel, D.W., 1995. Kimia dan Ekotoksikologi Pencemaran. Univ. Indonesia Press.

3. Darmono. 1995. Logam Dalam Sistem Biologi Makhluk Hidup. Jakarta: Universitas Indonesia Press.

4. Farkas, A., Salanki, J \& Specziar, A. 2002. Relation between growth and the heavy metal concentration in organs of bream Abramis brama L. populating Lake Balaton. Arc. Environ. Contam. Toxicol, Vol. (43), p. 236-243.

5. Jardine, GC. 1993. Effect of Pollutant at the Ecosystem Level. Environmental Toxicology Seminar. October 20, 1993. Diponegoro Univ., Semarang Central Java.

6. Khairuman. D.S \& Gunad, B. 2005. Budidaya Ikan Mas Secara Intensif. Agromedia Pustaka. Jakarta.

7. Khotimah, K., Dariu, B \& Sasmito. B. 2013. Uji Aktivitas Senyawa Aktivitas Senyawa Aktif Alga Coklat (Sargassum filipendulla.) Sebagai Antioksidan Pada Minyak Ikan Lemuru (Sardinella longiceps)., Journal THPI Student Vol 1 (1), p.10- 20.

8. Lu, CF. 1995. Basic toxicology. (Toksikologi dasar. Asas, organ sasaran, dan penilaian resiko, diterjemahkan oleh E. Nugroho. (Edisi kedua). Universitas Indonesia Press. Jakarta.

9. Palar, H. 1994. Pencemaran dan Toksikologi Logam Berat. PT Rineka Cipta. Jakarta. Penerbit Universitas Indonesia. Jakarta.

10. Sahetapy, M.J. 2011. Toksisitas Logam Berat Timbal $(\mathrm{Pb})$ dan Pengaruhnya pada Konsumsi Oksigen dan Respon Hematologi Juvenil Ikan Kerapu Macan. Thesis. Pasca Sarjana IPB, Bogor.

11. Skoog, A. West, D., Holler, FJ \& Crouch, SR. 2002. Fundamentals of Analytical Chemistry. Hardcover: 992 pages, Publisher: Brooks Cole.

12. Supriyanto, C., Samin \& Kamal, Z. 2007. Analisis Cemaran Logam Berat Pb, Cu dan Cd Pada Ikan Air Tawar Dengan Metode Spektrometri Nyala Serapan Atom (SSA). Paper, presented at Seminar Nasional III SDM Teknologi Nuklir. Yogyakarta 21-22 November 2007. ISSN 1978-0176.

13. Triadayan, AE, Aryawati, R \& Diansyah, G. 2010. Pengaruh logam timbal $(\mathrm{Pb})$ terhadap jaringan hati ikan kerapu bebek (Cromileptes altivelis). Journal Maspari, Vol. 1 (01), p. 42 $-47$.

14. Wong, K.C \& Wong. M. H. 2002. Morphological and Biochemical Changes In The Gills of Tilapia (Oreochromis mossambicus) to Ambient Cadmium Exposure. Aquatic Toxicology. Vol 2 (48), p. 517 - 527. 